\title{
Meanings of Work for Manicurists and Hairdressers: Employees and Pejotizados*
}

\author{
Mariana Machado Souza** \& \&ivia de Oliveira Borges (1) \\ Universidade Federal de Minas Gerais, Belo Horizonte, MG, Brasil
}

\begin{abstract}
The research aimed to identify the differentiation of meanings of work among beauty salon workers, considering the work contracts and the functions performed (hairdressers and manicurists), in a context of pejotização and functions' internal hierarchy. We applied questionnaires to 171 manicurists and hairdressers with the following types of links: employee, informal, MEI pejotizado and MEI não pejotizado. The results indicated that employees perceive with greater intensity the work as a responsibility and as a way of being socially included, and more proportionality in social and financial retribution. They also indicated that manicurists experience with more intensity the characteristics of brutalization, discrimination and demand.
\end{abstract}

KEYWORDS: meaning of work, statistical analysis, employment, self-employment.

\section{Significados do Trabalho para Manicures e Cabeleireiros: Empregados e Pejotizados}

\begin{abstract}
RESUMO - A pesquisa teve como objetivo identificar a diferenciação do significado do trabalho entre trabalhadores de salões de beleza, segundo os vínculos de trabalho e as funções exercidas (cabeleireiros e manicures), em um contexto de pejotização ${ }^{1}$ e hierarquia interna das profíssões. Para tanto, aplicamos questionários estruturados em 171 manicures e cabeleireiros com os seguintes vínculos: empregado, informal, MEI pejotizado e MEI não pejotizado. Os resultados indicaram que os empregados percebem com maior intensidade o trabalho como responsabilidade e como maneira de ser socialmente incluído, além de perceberem maior proporcionalidade na retribuição social e financeira. Indicaram também que as manicures vivenciam mais intensamente características de embrutecimento, discriminação e demanda.
\end{abstract}

PALAVRAS-CHAVE: significado do trabalho, análise estatística, emprego, trabalho autônomo.

Assigning meanings to work is a subjective process, marked by the insertion of individuals in the world. Therefore, the way individuals attribute meanings to this social category and the facets that configure them are contingent on each situation, being strongly influenced by occupation, historical insertion, conditions, and work organization (Barros et al., 2017; Bastos et al., 1995; Bendassolli, 2009; Brief \& Nord, 1990; Tolfo \& Piccinini, 2007).

1 pejotização (process); pejotizados (characteristic of workers) - These words are used to name the process and the workers under these conditions. Hiring personnel who were ruled by employment relationship through legal entities, free of labor rights.
In Brazil, the beauty sector, historically marked by informality, has undergone legal changes regarding labor relations. The Lei do Salão Parceiro (Partner Salon Law No. 13.352/2016) authorized the partnership between beauty salons and professionals, requiring the characterization of the latter as a legal entity. The records have been mostly in the tax form of a Microempreendedor Individual (MEI, Individual Micro Entrepreneur). From then on, a reality of different working relations practiced in beauty salons has been configured, making it possible to identify informal workers, employees ruled by the Consolidation of the Brazilian Labor Laws (CLT - Law 5452, as of 1943) and partner MEIs.

\footnotetext{
* This research was supported by Conselho Nacional de Desenvolvimento Científico e Tecnológico - CNPq

** E-mail:mmachadosouza@gmail.com

n Submetido: 08/10/2018; Revisado: 26/06/2020; Aceito: 02/09/2020.
} 
The characterization of workers of this sector as MEIs guarantees, in part, that they are formalized. However, there is also the option of hiring professionals who were employed under the CLT rules as legal entities ( $\mathrm{PJ}$ - pessoa jurídica). Then, the employment relationship is covered by the legal relationship of a civil nature, characterizing what has been called pejotização (Oliveira, 2013; Pereira, 2013).

Alongside this phenomenon, there is a hierarchy of professions within beauty salons. Manicurists (or nail technicians) occupy a place of lesser social recognition and prestige, while hairdressers represent the function of higher salaries and are related to an artistic work of greater prestige and competence (Arango \& Pineda, 2012; Dweck \& Sabbato, 2006; Oliveira, 2014).

In the scenario of this internal hierarchy of functions within beauty salons and changes in the legal frameworks that regulate the sector and promote labor flexibility, we questioned whether this reality interferes in the relationships of individuals with their own work and in the construction of meanings related to it. Therefore, we planned the present research with the objective of identifying the differentiation of the meanings of work among beauty salon workers in the city of Belo Horizonte, in the state of Minas Gerais (Brazil), according to the working relations (employees and MEI workers) and the functions performed (hairdressers and manicurists).

\section{Meanings of work: theoretical framework}

Although some studies were carried out before the 1980s (e.g., Morse \& Weiss, 1955; Williams et al., 1975), it was from this time that studies on the meaning of work were consolidated in Work and Social Psychology. In these studies (e.g., Bastos et al., 1995; Brief \& Nord, 1990; MOW, 1987; Salmaso \& Pombeni, 1986), the concept of the meaning of work as a multifaceted subjective and social cognition is predominant, but there is no consensus in relation to which facets comprise it (Borges \& Tamayo, 2001).

Among the consolidated studies from that decade, the transnational study by the Meaning of Work International Research Team (MOW) marked the field of knowledge and contributed to the understanding of the phenomenon, as recognized by several authors (e.g., Arnoux-Nicolas et al., 2016; Bastos et al., 1995; Bendassolli, 2009; Borges, 1999; Goulart, 2009; Pereira \& Tolfo, 2016). The results from that research demonstrated a high centrality of work for the 14,700 workers from different occupational sectors and the empirical analysis of the structure of the meaning of work pointed to four dimensions: centrality of work, societal norms, results, and valued objectives.

There is consensus in literature that the centrality of work - a general indicator regarding the value of work in the subject's life at a given moment (MOW, 1987) - is a facet of the meaning of work (Borges, 1997). However, Brazilian researchers who applied the MOW model (e.g., Bastos et al., 1995; Soares, 1992) showed that local specificities interfere with the application of the other dimensions described. In addition, studies like Martin-Baró's (1990) have shown the importance of considering the historical aspects of society and also the dialectic inherent in the construction of meaning to work that articulates experiences of joy and suffering.

Considering the characteristics of the Brazilian population and the differences found in the application of the MOW model in the country, Borges and Tamayo (2001) proposed a model for understanding the phenomenon. They considered the meaning of work as a dynamic, complex, and unfinished social and subjective cognition (Borges \& Tamayo, 2001). The model understands the phenomenon from four facets: (1) centrality of work, which concerns the importance that the individual attributes to work in comparison to other spheres of life (leisure, community, religion, and family); (2) value attributes, the definitions of what it should be; (3) descriptive attributes, which relate to the perception of work in its concrete reality; and (4) hierarchy of attributes, which means the individual arrangements of the value and descriptive attributes, according to their order of importance.

Since the first studies with the Inventário do Significado do Trabalho (IST, Meaning of Work Inventory - Borges, 1997, 1999), the value and descriptive attributes presented different factorial structures. In other words, when the worker reflects on what the job should be, the attributes are organized in a way, and when he or she thinks about what the job really is, the attributes are organized according to different criteria (Borges \& Barros, 2015).

Due to the dynamism of the meaning of the work, the factor structure of the value and descriptive attributes (IST items) has been reviewed in different studies (e.g., Borges, 1999; Borges \& Barros, 2015; Borges \& Tamayo, 2001; Borges \& Yamamoto, 2010). The most recent structure, identified by Borges and Barros (2015), emerged from a survey of 411 construction workers in the city of Belo Horizonte, Brazil (Table 1). In previous studies, the IST factors found were also correlated, leading to the option of an oblique factor analysis. Borges and Barros (2015), like Borges and Yamamoto (2010), used the SSA (Smallest Space Analysis) technique to be able to discriminate them better in attribute types, without losing consistency.

Studies carried out with IST were conducted with different categories, such as psychologists (Borges \& Yamamoto, 2010), construction workers (Barros \& Borges, 2016), disabled workers from different segments and regions of Brazil (Tette et al., 2014), teachers (Heleno et al., 2018), and rural workers (Barros \& Araújo, 2018). The uniqueness of the model by Borges and Tamayo (2001) is in the application, which is adapted to the Brazilian reality and in the possibility of application to low-literacy audiences, as well as in the non-exclusive range of desirable aspects (e.g., achievement and dignity) and of suffering (e.g., humiliation and exploitation) of their work experiences, highlighting the dialectical characteristic of the phenomenon (Borges $\&$ Barros, 2015). 
Table 1

Value and descriptive attribute types of the meaning of work

\begin{tabular}{|c|c|c|}
\hline Attributes & Factors & Definition \\
\hline \multirow{6}{*}{ Value } & $\begin{array}{l}\text { Source of achievement and economic } \\
\text { independence }(\alpha=0.73)\end{array}$ & $\begin{array}{l}\text { Being pleasant, for professional, social, and personal growth, and for satisfaction in } \\
\text { achievements and results (recognition and independence). }\end{array}$ \\
\hline & $\begin{array}{l}\text { Expression of respect and welcoming }(\alpha \\
=0.86)\end{array}$ & $\begin{array}{l}\text { Promoting an environment of trust, respect, and quality, in which the worker has social } \\
\text { and professional assistance. }\end{array}$ \\
\hline & Self-affirmation $(\alpha=0.65)$ & $\begin{array}{l}\text { Generating, within workers, the recognition of their qualities, responsibilities, merits, } \\
\text { and the social utility of work. }\end{array}$ \\
\hline & Dehumanizing and exhausting $(\alpha=0.76)$ & $\begin{array}{l}\text { Being exhausting, requiring agility and work overload, and being also cruel, exploring, } \\
\text { undervaluing, and discriminating. }\end{array}$ \\
\hline & Representative of difficulties $(\alpha=0.74)$ & $\begin{array}{l}\text { Demanding fast and repetitive physical efforts, encompassing the idea of being heavy } \\
\text { and physically demanding. }\end{array}$ \\
\hline & $\begin{array}{l}\text { Source of challenge, responsibility, and } \\
\text { livelihood }(\alpha=0.68)\end{array}$ & $\begin{array}{l}\text { Being challenging and consciously performed, with (intellectual) effort, being the } \\
\text { people's professions, and guaranteeing their livelihood. }\end{array}$ \\
\hline \multirow{10}{*}{ Descriptive } & Being dehumanized $(\alpha=0.61)$ & Seen as discriminating and brutalizing. \\
\hline & $\begin{array}{l}\text { Feeling exhausted and under pressure }(\alpha \\
=0.61)\end{array}$ & $\begin{array}{l}\text { Physically draining while demanding attention and putting people under pressure in the } \\
\text { execution of tasks. }\end{array}$ \\
\hline & $\begin{array}{l}\text { Facing demands and difficulties }(\alpha= \\
0.66)\end{array}$ & $\begin{array}{l}\text { Perceived as an activity full of routine and difficult tasks, since a lot is demanded and } \\
\text { little is received. }\end{array}$ \\
\hline & Be responsible (people) $(\alpha=0.68)$ & $\begin{array}{l}\text { Perceived as a responsibility (for what is produced) and a way of feeling socially } \\
\text { included (for being busy). }\end{array}$ \\
\hline & Challenging $(\alpha=0.72)$ & $\begin{array}{l}\text { Being challenging and consciously performed, with (intellectual) effort, bringing } \\
\text { personal satisfaction in relation to the results obtained. }\end{array}$ \\
\hline & Economic growth $(\alpha=0.75)$ & $\begin{array}{l}\text { A source of growth, learning and dignity, through which financial support and } \\
\text { independence are achieved. }\end{array}$ \\
\hline & $\begin{array}{l}\text { Feeling pleasure and protection }(\alpha= \\
0.63)\end{array}$ & $\begin{array}{l}\text { Source of pleasure and satisfaction in what is done, while feeling assisted by labor and } \\
\text { safety regulations. }\end{array}$ \\
\hline & $\begin{array}{l}\text { Contributing socially and being assisted } \\
(\alpha=0.69)\end{array}$ & $\begin{array}{l}\text { Seen as a contribution to the growth of society, in addition to providing adequate } \\
\text { assistance for carrying out the activity and for personal development. }\end{array}$ \\
\hline & Being recognized $(\alpha=0.76)$ & $\begin{array}{l}\text { A source of recognition of what is done, as something important for society, and of } \\
\text { valuing the participation of the worker in the production process. }\end{array}$ \\
\hline & Equitable payment $(\alpha=0.66)$ & $\begin{array}{l}\text { It is everyone's duty and right to be paid in proportion to the commitment to carrying } \\
\text { out the activities (socially and financially). }\end{array}$ \\
\hline
\end{tabular}

Note: Adapted from Borges and Barros (2015).

\section{Working in the beauty sector}

According to the Associação Brasileira da Indústria de Higiene Pessoal, Perfumaria e Cosméticos (Brazilian Association of the Personal Hygiene, Perfumery, and Cosmetics Industry - ABIHPEC, 2018), the beauty sector in the country, which represents $6.9 \%$ of the global consumption, presented an average deflated growth close to $4 \%$ in the last 10 years, with a $72.2 \%$ increase in job opportunities in beauty salons in the period. Aspects such as the increase in the participation of women in the labor market, the increase in life expectancy and income, the transformation of beauty into an important economic variable, the expansion of the service sector, and the development of new technologies contributed to this growth (ABIHPEC, 2018; Dweck \& Sabbato, 2006).

The beauty market and the working relations developed in it are historically marked by informality. Beauty salons are often opened in the professionals' own homes (Dweck \&
Sabbato, 2006; Garbaccio, 2013; Oliveira, 2014; Oliveira et al., 2015). In a study carried out with manicurists, Oliveira (2014) also pointed out signs of "simulated" formality in employment relationships. The interviewed professionals were formally hired, signed payment receipts, but their remuneration was actually based on commissions, that is, on the production of the month. In addition, salons used to abstain from paying social security contributions.

Law No. 12.592/2012, which recognizes the professions of manicurists, hairdressers, barbers, beauticians, hair removal professionals, and make-up artists, was amended by Law No. 13.352/2016 (the Partner Salon Law), to provide for the partnership regime between professionals and beauty salons. From then on, the autonomy of these professionals was regulated, and the partnership was formalized in a written contract. The justification for the change was the peculiarities present in the reality of beauty salons and the intention to encourage the formalization of the work of professionals. The law stipulates the responsibility of 
the partner salon for payments and receipts, forwarding a percentage of the amount paid for the service to the partner professional (Lei n. ${ }^{\circ}$ 13.352, 2016).

The law also stipulates that partner professionals be qualified as small entrepreneurs, micro entrepreneurs, or individual micro entrepreneurs (MEIs) (Lei n. ${ }^{\circ}$ 13.352, 2016), the latter being a legal figure created in 2008 with the aim of formalizing enterprises and promoting social security and inclusion (Souza et al., 2016). Its reach is revealed in the $716.5 \%$ growth in the number of MEIs (from 60,767 to 496,141 MEIs in the sector) in the Hairdressing, Manicure, and Pedicure activities from 2010 to 2016.

The figure of the MEI and the authorization of partnership contracts between professionals and beauty salons allow professionals to leave informality, acquiring social security and rights. However, the same process also allows companies to be exempted from the typical costs and obligations of employment relationships from the moment their professionals, who were governed by the CLT rules, become partner companies. This implies the use of the legal entity (PJ) to cover up an employment relationship, presenting it as a legal relationship of a civil nature. Pereira (2013) and Oliveira (2013) evidenced that this phenomenon, culturally called pejotização, has contributed to the precariousness of working relations in the sector.

Pejotização is inserted in the broad socioeconomic changes (flexible accumulation) of the last decades, consistent with the principles of economic liberalism. The new management methods have been aimed at reducing business costs and accelerating the flexibility of working relationships between sectors, companies, and jobs. Flexibility allows more freedom of using, hiring, and remunerating the companies' workforce. Thus, different working relations coexist within the same organization (Alves, 2013; Antunes, 2007, 2018; Arnold \& Bongiovi, 2013; Hewison, 2016; Krein, 2013). Precariousness appears as the strongest implication of this process (ThébaudMony \& Druck, 2007) and is characterized by uncertainty, vulnerability, instability, and insecurity in the work situation (Hewison, 2016; Standing, 2017). In precarious work, the worker assumes the risks of exercising his or her professional activity (instead of the company and the government), with losses in well-being, health, and social protection, in addition to the disruption of the working class, their working and personal time (Antunes, 2018; Kalleberg \& Hewison, 2013).

In practice, until 2016, this logic advanced in Brazil based mainly on measures approved for specific audiences, such as legal entities and micro and small companies (Krein, 2013; Krein \& Biavaschi, 2015). Law No. 13.352, of October 27, 2016 - the Partner Salon Law, mentioned earlier - is an example of one of these measures.

Due to the dynamic and socio-historical character of the meaning of work, as discussed in the previous section, we hope that the changes in the legal scope in the beauty sector and the characteristics evidenced in literature for the reality of precarious work reflect in different attributions of meanings to the work according to the different working relations practiced, with these being: employees, informal workers, employees becoming legal entities (MEI pejotizado), and informal workers becoming legal entities (MEI não pejotizado).

Considering the justifications for the creation of the MEI rules and its application in working relations within beauty salons, encompassing, among other aspects, the promotion of the formalization of work and regulating forms of payment, those who underwent pejotização did so through an aspiration of having greater financial gains and the freedom to provide services in their work lives. This justifies the hypothesis that: (H1) value attributes scores on the Self-affirmation and Source of Achievement and Economic Independence are higher for MEI pejotizado professionals in relation to the scores of the others (employees, informal workers, and MEI não pejotizado professionals).

Among the consequences that new forms of hiring can promote are the suppression of rights and benefits arising from labor legislation. In fact, the change to a legal entity modifies working relations to a relationship between two companies, which leads us to the hypothesis that: (H2) for MEI pejotizados, the descriptive attribute (perception of concrete work) Feeling Pleasure and Protection will present lower scores and Feeling Exhausted and Under Pressure will present higher scores in relation to the other professionals (employees, informal workers, and MEI não pejotizado professionals).

In addition, becoming a legal entity and being responsible for its financial gains may reflect an economic return proportional to the effort, since the remuneration would be the commissioning on the service provided. For this reason, the hypothesis of finding: (H3) higher scores for MEI pejotizado workers, in relation to the other working relations (employees, informal workers, and MEI não pejotizado professionals), in the Equitable Payment descriptive attribute type.

In addition to the coexistence of different working relations in beauty salons, their insertion in the service sector contributes to the exposure of workers to a psycho-affective burden, in addition to physical overload, requiring the selfregulation of behaviors and attitudes (Arango, 2011; Moura et al., 2017; Oliveira, 2014). The service sector is marked by intangibility, in which production and consumption are simultaneous and the consumer participates in the production process in the work environment (Meirelles, 2006).

Occupational and ergonomic risks were prevalent in previous studies (e.g., Aweto et al., 2015; Barbosa et al., 2015; Garbaccio \& Oliveira, 2012; Moura et al., 2017; Oliveira et al., 2015). Among the risks, these studies indicated, mainly, the chemical components (of the products used in the procedures), physical agents (such as noise and those related to work organization), issues related to inadequate postures, being under pressure from deadlines, 
long workdays, repetitive movements, and lack of control about the organization (Moura et al., 2017; Oliveira, 2014). For manicurists, there is also the risk of transmission of diseases, such as Hepatitis B and mycoses, in the removal of the cuticle of clients (Garbaccio, 2013).

Workers in beauty services act in different occupational functions, the majority of whom are hairdressers and manicurists. A characteristic of these occupations is the womanly predominance (Dweck \& Sabbato, 2006). In addition, Oliveira (2014) pointed out differences in the treatment and remuneration of functions, with manicurists being little remembered and hairdressers being the best paid professionals, reflecting the strategy of payment through commissions. Although the service is the most sought after in salons, it is viewed in lower positions in the social hierarchy of professions within beauty establishments. There is also the inconvenience, in Brazil, of the same word, "manicure", designating the service that is performed and, at the same time, the professional (Oliveira, 2014).

According to Oliveira (2014), who sought to understand the work of manicurists in Brazil, the social representation of the profession involves aspects related to women and domestic work, of low prestige and remuneration. The author also pointed out the intersections of gender bias since the historical origin of the manicurist profession, being a typical women's self-care activity, possible to be performed by any woman.

Oliveira (2014) and Arango and Pineda (2012) pointed out a clear economic and prestige-related advantage for men. Hairdressers, with a greater representation of men, are considered the main professionals in the beauty salon and their work is associated with "artistic making" and greater competence. This can be evidenced even by the greater existence of hairdressers who own the salons and who give their name to their businesses.

In Bogotá, Arango and Pineda (2012) sought to understand and analyze the differences and inequalities of class and gender that structure work in beauty services. The beauty sector in Colombia has similar aspects to Brazil, such as the growth experienced in recent years, the marked informality, the precariousness of work and feminization. The authors found that the sexual division of labor in the salons generates effects of devaluation and revaluation of the knowledge and skills of women in the sector, revealing a contradictory and dialectical character of their experiences. If, on the one hand, hairdressing services with the greatest financial gains represent the maximum expression of male talent and professionalism; on the other hand, nail care, seen as "women's work", shows the emotional and relational skills exhibited by women, characteristics valued by clients in beauty salons (Arango \& Pineda, 2012).

In view of the inequalities in social representation and recognition of the two main functions exercised in beauty salons, and the different experiences that these workers have in their daily lives, we believe that the meanings attributed by them to work are different. This justifies providing in the general objective of this research to compare or oppose meanings of work between manicurists and hairdressers. Among the differences, we expect that: (H4) manicurists, compared to hairdressers, present higher scores in Dehumanizing and Exhausting and lower scores in Self-affirmation.

Regarding how the research participants will perceive the reality of work, we expect that the difference in social recognition and financial gains between hairdressers and manicurists will be reflected in: (H5) higher scores for hairdressers, in relation to manicurists, in the descriptive attributes Economic Growth and Being Recognized, and lower scores in Being Dehumanized and Facing Demands and Difficulties.

In reference to the centrality of work, we consider the stability observed in literature (e.g., Borges \& Yamamoto, 2010; MOW, 1987; Tette et al., 2014) and we expect that: (H6) the centrality of work is high for beauty sector workers, occupying the second place in relation to other spheres of life.

\section{METHOD}

\section{Participants}

We applied the structured questionnaires in a convenience sample of 171 workers from different beauty salons in the city of Belo Horizonte, with 77 manicurists and 94 hairdressers. All manicurists were women and $51 \%$ of hairdressers were men. The age of the participants ranged from 16 to 73 years old $(\mathrm{M}=36 ; \mathrm{SD}=11.7)$. The predominant educational level was complete secondary education $(48.5 \%)$, followed by incomplete secondary education (14.6\%).

Regarding the length of time in the beauty sector, there was a variation between 1 and 47 years $(M=14.5$; $S D=$ 10.5 ) and the length of time in the current beauty salon ranged from 1 month to 33 years $(\mathrm{M}=5$ years; $\mathrm{SD}=6.4$ years), with no significant difference between hairdressers and manicurists in the former $(\mathrm{t}=1.5 ; \mathrm{p}=0.67)$ and the latter $(t=-0.74 ; p=0,29)$. The number of hours worked per week varied from 15 to 75 hours $(M=48 ; S D=9.8)$, with no significant differences $(\mathrm{t}=-1.11 ; \mathrm{p}=0.60)$ between the means of manicurists $(M=47.1 ; \mathrm{SD}=9.1)$ and hairdressers $(\mathrm{M}=48.6 ; \mathrm{SD}=10.3)$.

Working relations with salons varied between individual micro-entrepreneurs (MEIs) (69\%), informal workers (19.9\%), employees (7.6\%), and business owners (3.5\%). Among MEIs, 34 (28.8\%) were MEI pejotizado professionals, that is, they had an employment contract before being hired 
as legal entities; among the other MEIs, 82 (69.5\%) were previously in the informal sector and $2(1.7 \%)$ did not report their previous working relations. The predominant monthly income was between 1.5 and 3 minimum wages (35.1\%), followed by $<1.5$ minimum wages $(33.3 \%)$, between $3-5$ $(20.5 \%)$, and $>5$ minimum wages $(11.1 \%)$. Among the participants who reported receiving more than 5 minimum wages $(\mathrm{N}=19), 84.2 \%$ are hairdressers.

\section{Instruments}

We applied structured questionnaires, namely: a sociodemographic form, questions about the centrality of work (MOW, 1987; Soares, 1992) and the IST (Borges \& Barros, 2015). The sociodemographic form aimed to characterize the participants, within limits, to maintain their anonymity. The questions about the centrality of work were about the importance of work on a scale of 1 to 7 , and the order of importance of the spheres of life (work, family, leisure, community, and religion). Therefore, they allowed us to identify the absolute and relative importance of work for beauty salon workers.

The adoption of the IST allowed to apprehend the value and descriptive attributes of the work's meaning according to the participants. The instrument consists of 68 items with phrases about the work and the participant presents two responses to each item: one relating to what the subject expects the work to be (value attributes) and another relative to what he or she considers the work really is (descriptive attributes). All participants responded using a Likert scale ranging from 0 to 4 .

\section{Field activities and data analysis procedures}

The field activities were carried out between JanuaryMarch, 2018. The first author of the article individually applied the questionnaires to the participants, in the professionals' own work environment, respecting the participants' work schedule in each beauty salon. The interaction was initiated by establishing rapport and by reading and signing the Informed Consent Form (ICF). Thus, it reiterated the voluntary and optional character of participation already mentioned in the booking contact. Considering the diversity of instruction levels and reading habits of the participants, a card was used with the Likert scale represented in shades of colors and a Pocket PC handheld computer to record responses (Borges \& Barros, 2015). The aforementioned author, therefore, followed the entire questionnaire answering process, clarifying doubts when they arose.

We transferred the answers from the structured questionnaires to the SPSS database (Statistical Package for Social Sciences), through which we performed descriptive and inferential statistical analysis. We recoded the IST responses to a scale of 1 to 5. Initially, we characterized the sample and estimated each individual's scores by value and descriptive attribute types according to the structure validated by Borges and Barros (2015), and the centrality of work scores. Then, we estimated the statistics of central tendency and dispersion and, to establish comparisons, we applied the $t$ test for the groups according to their professions (manicurists and hairdressers), and the ANOVA test for the groups according to their working relations (employees, informal workers, MEI pejotizado and MEI não pejotizado professionals). The application of the ANOVA test for repeated measures allowed us to identify the hierarchy of the value and descriptive attributes for the sample. The concept of attribute hierarchy (Borges \& Tamayo, 2001) led to raising the individual order of priority set forth. We differ from the application to make progress in the considerations due to the trend of occupational groups.

\section{RESULTS}

\section{Centrality of work}

For the first question about the importance of work on a scale ranging from 1 to 7 , the answers varied between 3 and 7 , with an average of $6.64(\mathrm{SD}=0.76)$ and a concentration of $12.9 \%$ and $77.2 \%$ of the participants respectively answering 6 and 7 (Table 2). In the second question, regarding the order of importance of the spheres of life (work, leisure, family, religion, and community), $68.4 \%$ of the participants had the family sphere as the most important one. Leisure and community occupied the fourth and fifth places, with $49.1 \%$ and $78.9 \%$ of the answers, respectively.

The general tendency of the sample to place work and religion in second and third is not very evident (Table 2). The work sphere was second for $45 \%$ and the third for $38.6 \%$ of the sample, with high frequencies for both items. Regarding the Religion sphere, it was dispersed between first (25.7\%), second (19.9\%), third (22.8\%), and fourth places (22.2\%). 
Table 2

Organization of the five spheres of life, in order of importance $(N=171)$

\begin{tabular}{|c|c|c|c|c|c|c|c|c|c|c|}
\hline & \multicolumn{2}{|c|}{1} & \multicolumn{2}{|c|}{2} & \multicolumn{2}{|c|}{3} & \multicolumn{2}{|c|}{4} & \multicolumn{2}{|c|}{5} \\
\hline & $\mathbf{n}$ & $\%$ & n & $\%$ & $\mathbf{n}$ & $\%$ & $\mathbf{n}$ & $\%$ & $\mathbf{n}$ & $\%$ \\
\hline Leisure & 0 & 0 & 13 & 7.6 & 55 & 32.2 & 84 & 49.1 & 19 & 11.1 \\
\hline Community & 0 & 0 & 1 & 0.6 & 6 & 3.5 & 29 & 17 & 135 & 78.9 \\
\hline Work & 10 & 5.8 & 77 & 45 & 66 & 38.6 & 17 & 9.9 & 1 & 0.6 \\
\hline Religion & 44 & 25.7 & 34 & 19.9 & 39 & 22.8 & 38 & 22.2 & 16 & 9.4 \\
\hline Family & 117 & 68.4 & 46 & 26.9 & 5 & 2.9 & 3 & 1.8 & 0 & 0 \\
\hline
\end{tabular}

\section{Value and Descriptive Attributes}

We calculated the scores of the participants for each value attribute types found by Borges and Barros (2015) and obtained the mean values, the standard deviation, and the distribution of the scores of the participants by interval (Table 3). The Respect for the Worker attribute type had the highest average $(\mathrm{M}=4.92)$ and Dehumanizing and Exhausting, the lowest $(M=2.64)$.

The results of the ANOVA test for repeated measures with post hoc (LSD) indicated that the participants organized the attribute types into five priority levels ( $p$ $<0.05$ ), shown in Table 3. Respect for the Worker was the most valued attribute type by the sample, indicating the importance of an environment of trust, respect, and quality for all workers. In the second priority level, two attribute types appeared: Source of Achievement and Economic Independence and Self-affirmation. The Challenge, Responsibility, and Livelihood attribute type occupied the third priority level. The two attribute types that had the lowest averages and occupied the fourth and fifth priority levels were, respectively, Representative of Difficulties and Dehumanizing and Exhausting.

Table 3

Mean and standard deviations of the scores of the value and descriptive attribute types, with percentages by response interval and priority levels ( $N=171)$

\begin{tabular}{|c|c|c|c|c|c|c|c|}
\hline \multirow{2}{*}{ Attribute types } & \multirow{2}{*}{ Mean } & \multirow{2}{*}{ SD } & \multicolumn{4}{|c|}{ Percentage of participants by interval (\%) } & \multirow{2}{*}{ Leve } \\
\hline & & & $\mathbf{x} \leq \mathbf{2}$ & $2<x \leq 3$ & $3<x \leq 4$ & $x>4$ & \\
\hline \multicolumn{8}{|l|}{ Value } \\
\hline Respect for the Worker & 4.92 & 0.13 & 0 & 0 & 0 & 100 & $1^{\text {st }}$ \\
\hline Self-affirmation & 4.81 & 0.25 & 0 & 0 & 1.76 & 98.24 & \multirow[b]{2}{*}{$2^{\text {nd }}$} \\
\hline $\begin{array}{l}\text { Source of Achievement and } \\
\text { Economic Independence }\end{array}$ & 4.79 & 0.17 & 0 & 0 & 0 & 100 & \\
\hline $\begin{array}{l}\text { Challenge, Responsibility, } \\
\text { and Livelihood }\end{array}$ & 4.68 & 0.33 & 0 & 0 & 52.63 & 94.73 & $3^{\text {rd }}$ \\
\hline Representative of Difficulties & 3.59 & 0.79 & 2.92 & 23.97 & 42.10 & 30.99 & $4^{\text {th }}$ \\
\hline Dehumanizing and Exhausting & 2.64 & 0.61 & 20.47 & 53.21 & 24.56 & 1.76 & $5^{\text {th }}$ \\
\hline \multicolumn{8}{|l|}{ Descriptive } \\
\hline Economic Growth & 4.70 & 0.32 & 0 & 0 & 5.84 & 94.15 & \multirow{2}{*}{$1^{\text {st }}$} \\
\hline Challenging & 4.67 & 0.35 & 0 & 0 & 7.01 & 92.98 & \\
\hline Being Responsible (people) & 4.51 & 0.37 & 0 & 0.06 & 11.69 & 88.88 & $2^{\text {nd }}$ \\
\hline Feeling Pleasure and Protection & 4.22 & 0.61 & 0.58 & 4.67 & 33.92 & 60.82 & \multirow{3}{*}{$3^{\text {rd }}$} \\
\hline $\begin{array}{l}\text { Contributing Socially and Being } \\
\text { Assisted }\end{array}$ & 4.18 & 0.51 & 0 & 2.34 & 37.43 & 60.23 & \\
\hline Facing Demands and Difficulties & 4.16 & 0.54 & 0.06 & 4.10 & 33.33 & 61.99 & \\
\hline Being Recognized & 3.99 & 0.60 & 0.58 & 8.19 & 40.35 & $\mathbf{5 0 . 8 8}$ & $4^{\text {th }}$ \\
\hline Equitable Payment & 3.66 & 0.59 & 0.58 & 18.71 & 53.80 & 26.90 & \multirow[b]{2}{*}{$5^{\text {th }}$} \\
\hline $\begin{array}{l}\text { Feeling Exhausted and Under } \\
\text { Pressure }\end{array}$ & 3.54 & 0.79 & 5.84 & 22.81 & 48.53 & 22.81 & \\
\hline Being Dehumanized & 2.59 & 1.10 & 36.26 & 37.42 & 19.30 & 7.02 & $6^{\text {th }}$ \\
\hline
\end{tabular}


Despite presenting the lowest averages, Table 3 shows a greater distribution of responses by interval in these last two attribute types. This expresses that there is greater heterogeneity in the responses, so that there are workers who believe that the work must indeed present characteristics of difficulties, dehumanization, and fatigue. Regarding the Representative of Difficulties attribute type, most $(42.10 \%)$ highly value the requirement of physical efforts and a considerable portion of the participants (30.99\%) give maximum value to it. Regarding the Dehumanizing and Exhausting attribute type, most (53.21\%) value less the characteristics of fatigue, exploitation, and undervaluation by work.

We performed a t-test to compare the value attribute types between manicurists and hairdressers, and ANOVA to compare them according to the working relations with the beauty salon - employees, MEI pejotizado and MEI não pejotizado professionals, and informal workers. No significant differences were found in both tests.

In the same way that we proceeded with the value attributes, we calculated the scores of the descriptive attribute types found by Borges and Barros (2015). We present the mean and standard deviation values and the distribution of participants by response range in Table 3 . Economic Growth had the highest average (4.70) and Being Dehumanized had the lowest (2.59).

According to the results of the post hoc test (LSD), we built a ranking with six levels of priority for the descriptive attribute types $(p<0.05)$. In the first level, there are the descriptive attribute types of Economic Growth and Challenging, showing that almost all participants (94.15\% and $92.98 \%$, respectively) perceive in the work reality characteristics of challenge and intellectual effort, as well as a way of making a living and achieving financial independence.

The Being Responsible (people) attribute occupied the second level, representing the work of the participants as a way of feeling socially included and responsible for the achieved results. The third level of the ranking covered the Facing Demands and Difficulties, Feeling Pleasure and Protection, and Contributing Socially and Being Assisted attribute types, revealing the simultaneous perception of both positive and negative aspects at work.

In the fourth position, the Being Recognized attribute type reveals the perception of the importance of the participants in the work process and in society. In Table 3 , we also found that $50.88 \%$ of the participants described that in work with scores close to the maximum $(x>4)$, a large amount $(40.35 \%)$ described their presence, but not as strongly (interval responses between 3 and 4). Feeling Exhausted and Under Pressure and Equitable Payment were the attribute types that occupied the fifth level, revealing a higher frequency of responses in the range between 3 and 4 on the scale.

Finally, Being Dehumanized occupied the sixth level, revealing a lower perception of work as discriminating and brutalizing. Despite this, there is a significant proportion of responses in the score ranges between 2 and $3(37.42 \%)$ and a considerable frequency between 3 and 4 (19.30\%), indicating a perception, albeit low, of these characteristics.

We performed statistical analysis ( $t$ test) to compare the attribute types of descriptive attributes between manicurists and hairdressers. The results showed a significant difference for Being Dehumanized $(t=2.076 ; p<0.05)$ and Facing Demands and Difficulties $(t=3.101 ; p<0.05)$. In both attribute types, the mean responses of manicurists $(\mathrm{M}=2.79$ and $\mathrm{SD}=1.10$ for Being Dehumanized; $\mathrm{M}=4.29$ and $\mathrm{SD}=$ 0.45 for Facing Demands and Difficulties) were higher than those of hairdressers $(\mathrm{M}=2.49$ and $\mathrm{SD}=1.09$ for Being Dehumanized; $\mathrm{M}=4.08$ and $\mathrm{SD}=0.59$ for Facing Demands and Difficulties).

In order to identify whether the differences between the mean scores, according to the participant's working relations to the beauty salon (employees, informal workers, and MEI pejotizado and não pejotizado professionals), were significant, we performed an analysis of variance (ANOVA). We found differences in the attributes of Equitable Payment $(\mathrm{F}=2.77 ; \mathrm{p}<0.05)$ and Being Responsible (people) $(\mathrm{F}=$ 3.07; $\mathrm{p}<0.05$ ). Through the post hoc test (LSD), we found that employees had higher averages than MEI pejotizados and informal workers.

\section{DISCUSSION}

In view of the absence of significant differences between the scores in the participants' value attributes, regarding the function performed and the different working relations with the beauty salons, hypotheses H1 and H4 were rejected. Independently of the profession and the type of working relations, workers tend to prioritize the respect and selfrecognition that work should provide, followed by economic values (economic independence and livelihood) and, finally, the characteristics of difficulties and dehumanization. These results were like those found by Borges and Barros (2015) for construction workers.

$\mathrm{H} 2$ and $\mathrm{H} 3$ were rejected. The descriptive attributes Feeling Pleasure and Protection and Feeling Exhausted and Under Pressure did not present significant differences between participants of different working relations. With $\mathrm{H} 3$, we predicted that the average scores of MEI pejotizados in the descriptive attribute Equitable Payment would be higher than that of the other participants due to the possibility of greater financial gain through the commission system and 
social gain due to the transition to the title of "entrepreneur"; however, the results showed a differentiation in the average of employees, which was more valuable compared to the average of MEI pejotizados and informal workers. This expresses that, despite these aspects that we considered when proposing hypothesis 3 , it is the professionals regulated by the CLT that are given the most proportional remuneration, both social and financial, to the commitment in the activities. We also note that, in general, the averages had lower values, predominantly in the 3-4 range, indicating that, independently of their working relations, such workers tend not to feel high levels of justice and recognition.

In addition to the differentiation in Equitable Payment, another descriptive attribute that had a higher and significantly different average score for employees in the face of MEI pejotizados and informal workers was Being Responsible (people). In general, all averages had high values (all above 4.3), revealing a high perception of work as a responsibility and as a way of being socially included. However, for employees, this perception proved to be even greater. Once again, the typical employment relationship, defined by the CLT, guaranteed a greater perception of positive aspects in relation to the reality of work. Such results reflect the effects described by literature (Hewison, 2016; Krein, 2013) for flexible and precarious work, such as increased uncertainty, vulnerability, and insecurity. On the contrary, they contribute to deconstruct the expectations created and/or disseminated around the legislation that regulates the condition of MEIs and which was called the "Partner Salon Law". In other words, the results indicate that pejotização is not an outlet that improves the worker's life.

Regarding the hierarchy of descriptive attributes, the six levels found (Table 3 ) for workers in the beauty sector were similar to those described for construction workers (Borges \& Barros, 2015), for rural workers (Barros \& Araújo, 2018), and for metallurgists (Peixoto \& Borges, 2015). It is interesting to note that, although the Feeling Exhausted and Under Pressure and Being Dehumanized attribute types had the lowest averages in relation to the others, their scores showed greater dispersion. Therefore, even though the characteristics of exhaustion, discrimination, and brutalization are weakly shared by the sample participants, a large part still describes them in an extreme way $-71.34 \%$ had a score above 3 for Feeling Exhausted and Under Pressure, and $26.32 \%$ had a score above 3 for Being Dehumanized. There are, therefore, the prevalence of these meanings for a large number of participants, so we should ask ourselves about management practices, as well as how much the participants need to work to have an adequate livelihood. We suggest that future studies explore these dimensions, which are probably dialectically complementary.

H5 was partially accepted. On the one hand, the scores for the Economic Growth and Being Recognized attribute types did not show significant differences between manicurists and hairdressers. On the other hand, the scores in the Being Dehumanized and Facing Demands and Difficulties attribute types presented significantly different averages, being higher for manicurists. This means that they experience the characteristics of brutalization, discrimination, and demand more intensely, corroborating what is described in literature (Arango \& Pineda, 2012; Oliveira, 2014). We highlight the total of female manicurists, while for hairdressers there was a balance between men (51\%) and women $(49 \%)$, in line with what Oliveira (2014) and Arango and Pineda (2012) described in their studies, when confirming the presence of gender crossings in the activities of the beauty salon, with nail care being taken as women's work, secondary and underpaid, characteristics that may be related to the higher scores for Being Dehumanized and Facing Demands and Difficulties in the sample of the present research.

Regarding H6, part of it was corroborated by the high absolute centrality of work for the sample. Following the predominant trend found in literature that evaluated the order of importance that the participants attribute to the spheres of life (Barros \& Borges, 2016; Tette et al., 2014; MOW, 1987), family occupied the first position. However, contrary to expectations, there was no clear evidence as to whether work occupied the second or third position along with the religion sphere. This result is similar to the study by Barros and Borges (2016), carried out with construction workers, which indicated an interrelation between the family, religion, and work spheres. Once again, the perceptions of these occupational categories are similar, reinforcing the appropriate choice of the structure of the value and descriptive attribute types. These results stimulated us to inquire about the reasons that lead to such a rise in the importance of religion. Would it be the vulnerability of these professions (manicurists, hairdressers, and construction workers)? Would religiosity be prevalent in the state of Minas Gerais? Would we be witnessing the historic moment of the rise of some religions? We suggest exploring issues like these in future studies.

The result found for the relative importance of work in relation to other spheres is different from the findings of Brazilian studies such as the ones by Soares (1992), Bastos et al. (1995), and Barros and Araújo (2018), in which leisure ended in third place, behind family and work. This leads us to consider the possibility of the participants' place of origin influencing the prioritization of the spheres. Differently from the studies we cited, carried out in the Federal District and in the states of Bahia and Sergipe, the present research, as well as the study by Barros and Borges (2016), were conducted in the city of Belo Horizonte, in Minas Gerais, a state historically marked by strong religious features.

Through the study of the meanings of work, therefore, we were able to understand the social reality of workers in beauty salons. The rejection of the hypotheses constructed based on promises brought by the Partner Salon Law, such as those related to the autonomy of the professional, showed the 
contradictions between the workers' actual experiences and what was proposed in the legislation. The results pointed to the precariousness of work experienced by manicurists and hairdressers. In addition, the analysis of the hypotheses about the hierarchy of professions inserted in beauty salons, based on the results of previous studies, confirmed that manicurists and hairdressers have different experiences, which reflect in the way their meanings of the work are formulated.

\section{FINAL CONSIDERATIONS}

The research reached the objective of identifying the differentiation of the meanings of work among beauty salons workers in the city of Belo Horizonte according to the working relations (employees, informal workers, and MEI pejotizado and MEI não pejotizado professionals) and the functions performed (hairdressers and manicurists), indicating a relationship between the phenomenon of pejotização and the hierarchy of functions within the beauty salon and the way in which the participants relate to their own work.

As a limitation of the present study, we point out the insufficient number of participants for the exploration about the structure of the value and descriptive attributes, specific to the profession. Exploring the meanings in larger samples, especially when there is a wide variation in the level of education of individuals, as it is the case with professionals in the beauty sector, is indicated for future studies, so that statistical analysis, such as the SSA and factor analysis, are performed.

Finally, further studies are needed to better understand the working reality of the beauty sector, especially in the workers' perspective, and it is also possible to relate work meanings and pejotização with other phenomena such as working conditions and mental health. The performance of other field activities can complement the present findings. In addition, studies with other occupational categories that also experience the phenomenon of pejotização in an intense way, as is the case with journalists, teachers, and health professionals, is indicated so that it is possible to understand how the meanings attributed to work are configuring in this context of precariousness.

In view of the commonly lengthy process between project design, field activities, and, finally, publication, the timing of the participants' responses must be considered. As a consequence, and for the record, we would like to question what the results would be in the current year and in the years to come with the progress of labor reforms to make hiring more flexible, more pejotização and uberization, the expansion of the economic crisis, and the emergence of anxieties in the face of the COVID-19 pandemic.

\section{REFERENCES}

Associação Brasileira da Indústria de Higiene Pessoal, Perfumaria e Cosméticos -ABIHPEC (2018). Panorama do setor 2018. https://abihpec.org.br/publicacao/panorama-do-setor-2018/

Alves, G. (2013). Dimensões da reestruturação produtiva: Ensaios de Sociologia do Trabalho. Editora Canal 6.

Antunes, R. (2007). Dimensões da precarização estrutural do trabalho. In G. Druck, \& T. Franco (Eds.), A perda da razão social do trabalho: Terceirização e precarização (pp. 13-22). Boitempo.

Antunes, R. (2018). O privilégio da servidão: O novo proletariado de serviços na era digital. Boitempo.

Arango, L. G. (2011). Género, trabajo emocional y corporal en peluquerías y salones de beleza. La manzana de la discordia, 6(1), 9-24. doi: 10.25100/lamanzanadeladiscordia.v6i1.1506

Arango, L. G., \& Pineda, J. A. (2012). Género, trabajo y desigualdades sociales en peluquerías y salones de belleza de Bogotá. Revista CS, 10, 93-130. doi: 10.18046/recs.i10.1356

Arnold, D., \& Bongiovi, J. R. (2013). Precarious, informalizing, and flexible work: Transforming concepts and understandings. American Behavioral Scientist, 57(3), 289-308. doi: $10.1177 / 0002764212466239$

Arnoux-Nicolas, C., Sovet, L., Lhotellier, L., \& Bernaud, J. (2016). Development and validation of the meaning of work inventory among French workers. International Journal for Education and Vocational Guidance, 17, 165-185. doi: 10.1007/s10775016-9323-0

Aweto, H. A., Tella, B. A., \& Johnson, O. Y. (2015). Prevalence of work-related musculoskeletal disorders among hairdressers. International Journal of Occupational Medicine and
Environmental Health, 28(3), 545-555. doi: 10.13075/ ijomeh.1896.00291

Barbosa, L. D., Sasso, R. N., \& Amadei, J. L. (2015). Manicures/ pedicures: Conhecimento e práticas de biossegurança para hepatites virais. Revista Brasileira Promoção Saúde, 28(3), 361-369.

Barros, M. M. S., \& Araújo, M. R. M. (2018). Significado do trabalho para gerações de trabalhadores rurais no beneficiamento da castanha. Revista Psicologia: Organizações e Trabalho, 18(2), 364-372. doi: 10.17652/rpot/2018.2.13944

Barros, S., Borges, L. O., \& Álvaro, J. L. (2017). Economic changes and the meanings of work and Money. Journal of Work and Organizational Psychology, 33, 23-31. doi: 10.1016/j. rpto.2017.01.001

Barros, S., \& Borges, L. O. (2016). Significados do dinheiro e do trabalho: Um estudo com operários da construção de edificações de Belo Horizonte. Interação Psicologia, 20(2), 170-182. doi: $10.5380 /$ psi.v20i2.34365

Bastos, A. V. B., Pinho, A. P. M., \& Costa, C. A. (1995). Significado do trabalho: Um estudo entre trabalhadores em organizações formais. Revista de Administração de Empresas, 35(6), 20-29. doi: 10.1590/S0034-75901995000600004

Bendassoli, P. F. (2009). Psicologia e Trabalho: Apropriações e significados. Cengage.

Borges, L. O. (1997). Os atributos e a medida do significado do trabalho. Psicologia: Teoria e Pesquisa, 13(2), 211-220. doi: 10.1590/S1413-294X2001000200006

Borges, L. O. (1999). A estrutura fatorial dos atributos valorativos e descritivos do trabalho: Um estudo empírico de aperfeiçoamento 
e validação de um questionário. Estudos de Psicologia (Natal), 4, 107-158. doi: 10.1590/S1413-294X1999000100007

Borges, L. O., \& Tamayo, A. (2001). A estrutura cognitiva do significado do trabalho. Revista Psicologia: Organizações e Trabalho, 1(2), 11-44. http://pepsic.bvsalud.org/scielo. php?script=sci_arttext\&pid=S1984-66572001000200002

Borges, L. O., \& Yamamoto, O. H. (2010). O significado do trabalho para psicólogos brasileiros. In A. V. B. Bastos, \& S. M. G. Gondim (Eds.), O trabalho do psicólogo no Brasil (pp. 248 - 283). Artmed.

Borges, L. O., \& Barros, S. C. (2015). Inventário de significado do trabalho para trabalhadores de baixa instrução. In K. E. PuentePalácios \& A. Peixoto (Eds..), Ferramentas de diagnóstico para organizações e trabalho: Um olhar a partir da Psicologia (pp. 232-260). Artmed.

Lei $\mathrm{n}^{\mathrm{o}}$ 12.592, de 18 de janeiro de 2012 (2012). Dispõe sobre o exercício das atividades profissionais de Cabeleireiro, Barbeiro, Esteticista, Manicure, Pedicure, Depilador e Maquiador. Diário Oficial da União, Brasília, DF. http://www.planalto.gov.br/ ccivil 03/ ato2011-2014/2012/lei/112592.htm

Lei no 13.352, de 27 de outubro de 2016 (2016) . Altera a Lei no 12.592 , de 18 de janeiro 2012, para dispor sobre o contrato de parceria entre os profissionais que exercem as atividades de Cabeleireiro, Barbeiro, Esteticista, Manicure, Pedicure, Depilador e Maquiador e pessoas jurídicas registradas como salão de beleza. Diário Oficial da União, Brasília, DF. http:// www.planalto.gov.br/ccivil_03/_ato2015-2018/2016/lei/ L13352.htm

Brief, A. P., \& Nord, W. R. (1990). Meaning of occupational work: A collection of essays. Lexington Books.

Dweck, R. H., \& Sabbato, A. D. (2006). A beleza e o mercado de trabalho: Uma perspectiva de gênero. Revista Gênero, 7(1) 95128. http://www.revistagenero.uff.br/index.php/revistagenero/ article/viewFile/348/260

Garbaccio, J. L. (2013). Conhecimento e adesão às medidas de biossegurança entre manicures e pedicures (Tese de Doutorado não publicada). Universidade Federal de Minas Gerais. http:// www.enf.ufmg.br/pos/defesas/740D.PDF

Garbaccio, J. L., \& Oliveira, A. C. (2012). Biossegurança e risco ocupacional entre os profissionais do segmento de beleza e estética: Revisão integrativa. Revista Eletrônica de Enfermagem, 4(3), p. 702-711. doi: 10.5216/ree.v14i3.15018

Goulart, P. M. (2009). O significado do trabalho: Delimitações teóricas (1955-2006). Cadernos de Psicologia Social do Trabalho, 12, 47-55. http://pepsic.bvsalud.org/scielo. php? script $=$ sci arttext\&pid $=$ S1516-37172009000100005 \&lng $=$ pt\&nrm $=\overline{\text { iso }}$

Heleno, C. T., Borges, L. O., \& Agulló-Tomás, E. (2018). The meaning of work as a predictor of the intention to remain/leave among teachers. Revista de Administração Mackenzie, 19 (spe), eRAMD180017. doi: 10.1590/1678-6971/eramd180017

Hewison, K. (2016). Precarious work. In S. Edgell, H. Gottfried, \& E. Granter (Eds.), The SAGE handbook of the sociology of work and employment (pp. 428-443). SAGE Reference.

Kalleberg, A. L., \& Hewison, K. (2013). Precarious work and the challenge for Asia. American Behavioral Scientist, 57(3), p. 271-288. doi: 10.1177/0002764212466238

Krein, J. D. (2013). As transformações no mundo do trabalho e as tendências das relações de trabalho na primeira década do século XXI no Brasil. Revista do Núcleo de Estudo de Economia Catarinense, 2(3), 6-25. http://incubadora. periodicos.ufsc.br/index.php/necat/article/view/2785/3313

Krein, J. D., \& Biavaschi, M. B. (2015). Brasil: Os movimentos contraditórios da regulação do trabalho nos anos 2000 . Cuadernos del CENDES, 89, p. 47-82. http://saber.ucv.ve/ojs/ index.php/rev_cc/article/view/9895/9706
Lei n. ${ }^{\circ}$ 5452, de 1 de maio de 1943 (1943). Aprova a consolidação das leis do trabalho. http://www.planalto.gov.br/ccivil_03/ decreto-lei/del5452.htm

Martin-Baró, I. (1990). ¿Trabajador alegre o trabajador explotado? La identidad del salvadoreño. Revista Interamericana de Psicologia, 24(1), 1-24. http://www.uca.edu.sv/colecciondigital-IMB/articulo/trabajador-alegre-o-trabajador-explotadola-identidad-nacional-del-salvadoreno/

Meirelles, D. S. (2006). O conceito de serviço. Revista de Economia Política, 26(1), 119-136. doi: 10.1590/S010131572006000100007

Morse, H., \& Weiss, R. (1955). The function and meaning of work and the job. American Sociological Review, 20, 191-198. doi: $10.2307 / 2088325$

Moura, J. S., Mendes, D. P., \& Moraes, G. F. S. (2017). O custo humano de ser bonito(a): As (im)possibilidades de manutenção da saúde dos cabeleireiros de um instituto de beleza. Revista Laborativa, 6(especial Saúde Mental e Trabalho), 43-63. https://ojs.unesp.br/index.php/rlaborativa/article/view/1554/ pdf

MOW International Research Team. (1987). The meaning of working. Academic Press.

Oliveira, J. A. (2014). Fazendo a vida fazendo a unha: Uma análise sociológica do trabalho de manicure (Tese de doutorado não publicada). Universidade de São Paulo. http://www.teses.usp. br/teses/disponiveis/8/8132/tde-05032015-104355/en.php

Oliveira, L. M. (2013). Pejotização e a precarização das relações de emprego. Revista Atitude - Construindo Oportunidades, 7(14), 25-31. https://jus.com.br/artigos/23588/pejotizacao-ea-precarizacao-das-relacoes-de-emprego

Oliveira, M. N. M., Santos, M. S. N., Figueiredo, I. G. A., Lucena, J. D., Sousa, A. M., Uchoa, F. N. M., Oliveira, T. L., \& Freitas, A. P. S. (2015). Investigação da exposição ocupacional de manicure: Um estudo transversal. Revista Intertox-EcoAdvisor de Toxicologia Risco Ambiental e Sociedade, 8(2), 131-144. $\mathrm{http} / / /$ revistarevinter.com.br/minhas-revistas $/ 2015 / \mathrm{v}-8-\mathrm{n}-2$ 2015-volume-8-numero-2-junho-de-2015-sao-paulo/267investigacao-da-exposicao-ocupacional-de-manicure-umestudo-transversal/file

Peixoto, T. P., \& Borges, L. O. (2015). El sector metalúrgico: Relaciones sindicales, motivación y significados del trabajo. Revista Colombiana de Psicología, 24(1), 165-181. doi: 10.15446/rcp.v24n1.39907

Pereira, E. F., \& Tolfo, S. R. (2016). Estudos sobre sentidos e significados do trabalho na psicologia: Uma revisão das suas bases teórico epistemológicas. Psicologia Argumento, 34(86), 302-317. doi: 10.7213/psicol.argum.34.087.AO02

Pereira, L. (2013). Pejotização: O trabalhador como pessoa jurídica. Saraiva.

Salmaso, P., \& Pombeni, L. (1986). Le concept de travail. In W. Doise \& A. Palmonari (Eds.), L'étude des représentations sociales (pp. 196-205). Pelachaux \& Nestlé.

Soares, C. R. V. (1992). Significado do trabalho: Um estudo comparativo de categorias ocupacionais (Dissertação de Mestrado não publicada). Universidade de Brasília.

Souza, D. L., Souza, J. B., Pasin, L. E. V., \& Zambalde, A. L. (2016). Empreendedorismo e desenvolvimento local: Uma análise do programa Microempreendedor Individual em Minas Gerais. Desenvolvimento em Questão, 14(37), 262-292. doi: 10.21527/2237-6453.2016.37.262-292

Standing, G. (2017). O precariado: A nova classe perigosa (C. Antunes, Trans.). Autêntica Editora. (Originalmente publicado em 2013).

Tette, R. P. G., Carvalho-Freitas, M. N., \& Oliveira, M. S. (2014). Relações entre significado do trabalho e percepção de suporte para pessoas com deficiência em organizações brasileiras. Estudos de Psicologia (Natal), 19(3), 217-226. doi: 10.1590/ S1413-294X2014000300007 
Thébaud-Mony, A., \& Druck, G. (2007). Terceirização: A erosão dos direitos dos trabalhadores na França e no Brasil. In G. Druck, \& T. Franco (Eds.). A perda da razão social do trabalho: terceirização e precarização (pp. 23-58). Boitempo.

Tolfo, S. R., \& Piccinini, V. (2007). Sentidos e significados do trabalho: Explorando conceitos, variáveis e estudos empíricos brasileiros. Psicologia \& Sociedade, 19, 38-46. doi.10.1590/ S0102-71822007000400007

Williams, R. S., Morea, P. C., \& Ives, J. M. (1975). The significance of work: An empirical study. Journal of Occupational and Organizational Psychology, 48, 45-51. doi: 10.1111/j.20448325.1975.tb00296.x 